\title{
Pengaruh Pengungkapan Manajemen Risiko Terhadap Nilai Perusahaan Melalui Kinerja Keuangan Di Industri Perbankan Indonesia
}

\author{
Agung Supriyadi \\ Magister Akuntansi, Fakultas Ekonomi dan \\ Bisnis Universitas Jenderal Soedirman \\ agungsupriyadisenpai@gmail.com
}

\author{
Christina Tri Setyorini \\ Fakultas Ekonomi dan Bisnis \\ Universitas Jenderal Soedirman \\ Christina.setyorini@unsoed.ac.id
}

Corresponding Author: Agung Supriyadi

Submitted: 27 Juni 2020

Accepted: 03 Agustus 2020

Published: 03 Agustus 2020

\section{ABSTRAK}

Investors assess and demand banks to improve their risk management. Then, the profit earned by the bank is not yet known the effect of risk management on firm value. The aim of this study is to determine the effect of risk management disclosures on firm value with profitability as a mediating variable. The population used in this study are all banks listed on the Indonesia Stock Exchange (IDX) in the period of 2016 to 2018. This type of research is a correlational study consisting of thirty-six banks as research samples. Furthermore, the sampling method used in this study was purposive sampling. The results showed that the disclosure of risk management has a positive effect on profitability and firm value. Then, the risks and opportunities in this study can be managed well by the company so that it has a positive effect on increasing the company's profitability. The market implication assumes that risk management disclosures can be used as one of the relevant information to increase the value of the company. However, profitability in this study cannot mediate the relationship between risk management disclosure and firm value. The size of profitability produced in banks in Indonesia is not a determining factor in managing a company's risk management activities. So it can be concluded that risk management is disclosed solely because it fulfills corporate responsibilities and complies with government regulations.

Keywords : risk management disclosure, profitability, firm value, bank

\section{PENDAHULUAN}

Persaingan dalam perusahaan perbankan membuat setiap bank semakin meningkatkan kinerjanya agar dapat mencapai tujuan perusahaan. Tujuan utama perusahaan adalah memaksimalkan profit atau laba untuk meningkatkan nilai perusahaan. Nilai perusahaan merupakan nilai jual sebuah perusahaan sebagai suatu bisnis yang sedang beroperasi Sartono
(2010). Sedangkan menurut Fama (1978) menyatakan bahwa nilai sebuah perusahaan dapat dilihat dari harga saham. Verrechia (1983) menyatakan bahwa dari sudut pandang ekonomi, perusahaan akan mengungkapkan suatu informasi jika informasi tersebut akan meningkatkan nilai perusahaan. Harga pasar saham yang meningkat mencerminkan kepercayaaan masyarakat yang tinggi terhadap 
perusahaan. Mereka mau membayar lebih tinggi dengan harapan return yang lebih tinggi pula. Sehingga penting bagi perusahaan untuk memaksimalkan nilai perusahaan, karena dengan memaksimalkan nilai perusahaan berarti juga memaksimalkan kemakmuran pemegang saham Brigham \& Daves (2010).

Salah satu cara memaksimalkan nilai perusahaan adalah dengan mengelola risiko perusahaan dengan baik. Dalam penelitian Sugiyanto \& Rahayu (2018) "Risk Management sendiri merupakan salah satu praktik Good Corporate Governance". Perusahaan perlu menerapkan manajemen risiko untuk menunjukkan praktik Good Corporate Gorvernance yang dilakukannya. Penerapan manajemen risiko juga dapat dilakukan dengan menurunkan praktik manajemen laba untuk meningkatkan reputasi perusahaan melalui pengungkapan CSR dan lingkungan perusahaan Setyorini \& Ishak (2012).

Manajemen risiko perusahaan adalah suatu proses yang dipengaruhi oleh dewan direksi, manajemen, dan personil lain entitas, diterapkan dalam penetapan strategi perusahaan, yang dirancang untuk mengidentifikasi peristiwa potensial yang dapat memengaruhi entitas, dan mengelola risiko agar berada dalam risikonya Moeller (2011). Sedangkan pengungkapan sendiri merupakan bagian dari pelaporan perusahaan. Pengungkapan manajemen risiko memberikan sinyal kepada investor baik itu berupa berita baik maupun berita buruk sehingga dapat memengaruhi nilai perusahaan.

Salah satu bank yang gagal dalam mengelola risikonya adalah Bank Century. Kegagalan Bank Century dalam mengelola risikonya yang disebabkan ketidakpatuhan terhadap hukum perbankan yang berlaku, yaitu manajemen risiko dan manajemen perbankan pada umumnya. Bank Century merupakan bank yang mengalami krisis keuangan yang disebabkan bermasalahnya surat berharga valuta asing (valas) serta melakukan penjualan reksadana bodong yang membuat uang tersebut mengalir ke rekening Robert Tantular sebagai pemilik bank. Kasus tersebut membuat Bank Century diambil alih oleh LPS dan berubah menjadi PT Bank Mutiara,Tbk sampai dengan diakuisisi oleh $\mathrm{J}$ Trust Co.Ltd. Setelah diakuisisi oleh J Trust Co.Ltd membuat nilai perusahaan perlahan-lahan membaik. Berkaitan dengan nilai perusahaan dan manajemen risiko di bank, pada Oktober 2019 Perhimpunan Bank-bank Umum Nasional (Perbanas) mengatakan kondisi perbankan di 5 tahun terakhir pada masalah di kredit macet (NPL) dan likuiditas. Kondisi tersebut membuat kinerja manajemen perbankan dimasa yang akan datang harus memperbaiki manajemen risikonya, sehingga dapat menjadikan sinyal positif terhadap investor.

Penelitian sebelumnya yang dilakukan oleh Azim \& Abdelmoniem (2015) dan Devi et al.(2017), menunjukkan pengaruh positif yang signifikan antara pengungkapan manajemen risiko terhadap nilai perusahaan. Azim \& Abdelmoniem (2015), menyatakan bahwa pengungkapan risiko akan mengurangi eksposur risiko, sehingga akan meningkatkan nilai perusahaan. Selain itu, dengan mengelola risiko pasar, maka nilai perusahaan juga akan meningkat. Sebaliknya penelitian Anton (2018) dilakukan pada saat terjadi krisis global 2001 - 2008, menemukan bahwa manajemen risiko perusahaan tidak berpengaruh terhadap nilai perusahaan. Begitu juga penelitian yang dilakukan oleh Sayilir \& Farhan (2017) membuktikan tidak ada pengaruh antara manajemen risiko perusahaan terhadap nilai perusahaan. Berbedanya hasil penelitian di atas dapat disebabkan karena perbedaan kondisi ekonomi yang terjadi, dimana pada penelitian tersebut sedang 
terjadi krisis global. Profitabilitas perusahaan yang diperoleh pada krisis global berbeda dengan kondisi normal Sayilir \& Farhan (2017).

Teori sinyal menyatakan perusahaan dengan keuntungan yang tinggi akan sengaja memberikan sinyal sehingga adanya kenaikan volume penjualan saham. Variabel profitabilitas merupakan sinyal yang baik maupun buruk sehingga dapat menjadi syarat pengungkapan manajemen risiko. Beberapa penelitian telah menggunakan profitabilitas sebagi variabel mediasi. Penelitian yang dilakukan oleh Dianawati \& Fuadati, (2016) menggunakan profitabilitas sebagai variabel yang memediasi hubungan antara GCG dan CSR. GCG dan CSR dapat meningkatkan nilai perusahaan pada saat profitabilitas perusahaan tinggi, dan sebaliknya GCG dan CSR dapat menurunkan nilai perusahaan pada saat profitabilitas rendah. Penelitian yang menggunakan profitabilitas sebagai variabel yang memediasi hubungan antara manajemen risiko dan nilai perusahaan pernah dilakukan oleh Agustina \& Baroroh (2016).

Berdasarkan latar belakang diatas maka penelitian ini meneliti tentang pengaruh pengungkapan manajemen risiko terhadap nilai perusahaan dengan variabel intervening profitabilitas. Penelitian ini berfokus pada pengungkapan manajemen risiko menggunakan COSO framework 2017 dan perubahan nilai entitas perbankan di Indonesia dengan profitabilitas sebagai penentunya. Committe of Sponsoring Organization (COSO) of The Treadway Commision mengeluarkan kerangka terbarunya agar perusahaan dapat memperbaiki kinerja manajemen risikonya. Kerangka Enterprise Risk Management - Integrating with Strategy and Performance meliputi 5 komponen dan 20 prinsip.

\section{TINJAUAN PUSTAKA}

\subsection{Teori Sinyal}

Teori sinyal menyatakan bahwa perusahaan yang berkualitas baik dengan sengaja akan memberikan sinyal pada pasar, dengan demikian pasar diharapkan dapat membedakan perusahaan yang berkualitas baik dan buruk Hartono (2008). Teori sinyal juga menekankan pada pentingnya informasi yang dikeluarkan oleh perusahaan bagi keputusan investasi pihak di luar perusahaan. Teori signaling menggambarkan bagaimana semestinya suatu perusahaan memberikan indikasi kepada para pengguna laporan keuangan. Perusahaan dengan prospek yang kurang menguntungkan akan cenderung untuk menjual sahamnya Brigham \& Ehrhardt (2005). Sehingga, pada intinya teori pensinyalan menunjukkan bahwa pemberi sinyal merupakan orang dalam yang memperoleh informasi tentang seseorang, produk, atau organisasi yang tidak tersedia untuk orang luar Connelly et al. (2011). Pada tingkatan yang lebih, orang dalam memperoleh informasi, beberapa di antaranya positif dan beberapa di antaranya negatif, yang menurut orang luar bermanfaat. Orang dalam memperoleh informasi pribadi positif dan negatif, dan mereka harus memutuskan apakah akan mengomunikasikan informasi ini kepada orang luar. Teori pensinyalan berfokus terutama pada komunikasi yang disengaja dari informasi positif dalam upaya untuk menyampaikan atribut organisasi yang positif. Informasi negatif tentang atribut organisasi misalnya, mengeluarkan saham baru dari suatu perusahaan umumnya dianggap sebagai sinyal negatif karena eksekutif dapat menerbitkan ekuitas ketika mereka percaya harga saham perusahaan mereka dinilai terlalu tinggi Myers \& Majluf (1984). 


\subsection{Teori Stakeholder}

Freeman (1994), mendefinisikan bahwa pemangku kepentingan terdiri dari karyawan, pemodal, pelanggan, dan masyarakat. Teori Stakeholder dipandang lebih condong ke manajemen sehingga menunjukkan dan mengungkapkan bagaimana para manajer beroperasi di perusahaan dibandingkan dengan para ekonom Freeman et al. (2004). Freeman (1994), mengaitkan tujuan teori Stakeholder dengan fokus pada dua isu pokok, yaitu: pertama, berusaha mencari tahu tujuan perusahaan; ini membuat para manajer menilai diri mereka sendiri dalam hal nilai yang mereka ciptakan dan apa yang bisa membuat para pemangku kepentingan tetap bersama. Ini akan mengarah pada kinerja perusahaan yang lebih baik; kedua, berupaya untuk mengetahui tanggung jawab manajemen terhadap para pemangku kepentingan. Hal ini membuat manajemen mempertimbangkan jenis hubungan yang mereka inginkan untuk dibuat dengan pemangku kepentingan mereka. Manajer harus mengembangkan hubungan serta membuat pemangku kepentingan menjadi termotivasi dan menciptakan komunitas dimana setiap orang memberikan yang terbaik untuk menciptakan nilai bagi perusahaan Freeman et al. (2004).

Stakeholder dan organisasi saling memengaruhi, hal ini dapat dinilai dari hubungan keduanya yang berbentuk responsibilitas dan akuntabilitas. Semakin kuat hubungan perusahaan dengan stakeholder maka semakin baik bisnis perusahaan tersebut. Sebaliknya jika semakin buruk hubungan perusahaan dengan stakeholder maka akan semakin sulit bisnis perusahaan Donaldson \& Preston (1995). Konsep dari teori stakeholder adalah manajemen strategis, yaitu bertujuan untuk membantu memperkuat hubungan dengan pihak eksternal dan mengembangkan keunggulan kompetitif Hoyt \& Lienberg (2011). Teori Stakeholder mengatakan bahwa perusahaan bukanlah entitas yang hanya beroperasi untuk kepentingannya sendiri namun harus memberikan manfaat bagi stakeholdernya. Dukungan yang diperoleh dari stakeholder kepada perusahaan memberikan pengaruh terhadap keberadaan suatu perusahaan itu sendiri.

\subsection{Teori Agensi}

Jensen dan Meckling (1976) menyatakan bahwa hubungan keagenan merupakan sebuah kontrak antara manajer dengan pemilik saham. Perusahaan dapat sebagai satu rangkaian kontrak antara pihak-pihak yang berkaitan. Manajer dikontrak oleh pemegang saham untuk mengelola perusahaan agar perusahaan tersebut menghasilkan laba yang signifikan, sehingga dapat meningkatkan nilai perusahaan. Namun demikian, para manajer seringkali bertindak tidak sesuai kepentingan pemegang saham. Dalam hal ini adanya perbedaan antara kepentingan pemegang saham yang menginginkan pengembalian modal yang telah mereka investasikan dan manajemen yang menginginkan kompensasi yang wajar atas kinerja yang dihasilkan.

Hubungan keagenan masingmasing pihak baik manajer maupun pemegang saham bertujuan untuk kepentingannya sendiri. Manajer biasanya mempunyai lebih banyak informasi perusahaan dibandingkan pemegang saham. Hal tersebut memunculkan ketimpangan informasi, yang disebut dengan asimetri informasi Jensen dan Meckling (1976). Upaya untuk mengurangi asismetri informasi adalah melalui pengungkapan laporan keuangan Sutedja (2006). Pengungkapan manajemen risiko merupakan bagian dari informasi perusahaan tentang tata kelola perusahaan. Kerangka ERM merupakan bagian dari mekanisme tata kelola perusahaan dalam mencapai strategi dan tujuan bisnis sehingga manajer juga berhak mendapatkan imbalan atas kinerja 
mereka dalam mencapai tujuan perusahaan

\subsection{Nilai Perusahaan}

Nilai perusahaan adalah nilai jual sebuah perusahaan sebagai suatu bisnis yang sedang beroperasi Sartono (2010). Fama (1978) menyatakan bahwa nilai perusahaan dapat tercermin dari harga saham. Harga pasar saham yang meningkat mencerminkan kepercayaaan masyarakat yang tinggi terhadap perusahaan. Investor akan bersedia membayar saham tersebut lebih tinggi dengan harapan mereka akan mendapatkan return yang lebih tinggi pula. Sehingga penting bagi perusahaan untuk memaksimalkan nilai perusahaan, karena dengan memaksimalkan nilai perusahaan berarti juga memaksimalkan kemakmuran pemegang saham Brigham \& Daves (2010)

Brigham \& Houston (2014) menyatakan bahwa beberapa pendekatan analisis rasio dalam penilaian market value. Pendekatan tersebut terdiri price earning ratio (PER), price book value (PBV), market to book ratio (MBR), deviden yield ratio dan deviden payout ratio (DPR).

1. PER (Price Earning Ratio) merupakan rasio yang menunjukkan berapa banyak jumlah uang yang rela dikeluarkan oleh para investor untuk membayar setiap rupiah laba yang dilaporkan.

2. PBV (Price Book Value) merupakan rasio yang mengukur nilai pasar keuangan kepada manajemen dan organisasi perusahaan sebagai perusahaan yang terus tumbuh. Rasio PBV memiliki kelebihan yaitu nilai buku relatif stabil, nilai buku memberikan standar akuntansi yang konsisten dan perusahaan yang memiliki keuntungan negatif bisa diukur oleh PBV.

3. MBR (Market to Book Ratio) merupakan rasio yang menunjukkan perbandingan antara nilai/harga pasar saham terhadap nilai buku perusahaan yang diperoleh dari selisih antara nilai aktiva yang dimiliki oleh perusahaan dengan nilai kewajiban.

4. Deviden yeld ratio merupakan rasio keuangan yang membandingkan jumlah dividen tunai yang dibagikan kepada pemegang saham dengan harga saham.

5. DPR (Deviden Payout Ratio) adalah rasio keuangan yang digunakan untuk mengukur persentase laba bersih yang dibagikan kepada pemegang saham dalam bentuk dividen.

\subsection{Manajemen Risiko}

Manajemen risiko berperan dalam melindungi modal dan mengoptimalkan return terhadap risiko. Skala operasi yang luas dan volume usaha yang terus meningkat, membuat sektor perbankan di Indonesia harus menerapkan pola pengelolaan risiko secara terintegrasi untuk mengidentifikasi, mengukur, memantau dan mengendalikan seluruh eksposur risiko. Beberapa penelitian mengusulkan bahwa manajemen risiko perusahaan dapat mengurangi biaya kesulitan keuangan, meningkatkan penghindaran risiko manajerial, memitigasi pembayaran pajak yang diharapkan, menyelesaikan masalah kekurangan investasi dan memberikan kepercayaan bagi bisnis untuk melakukan proyek investasi baru. Manajemen risiko dapat meningkatkan kinerja perusahaan dengan mengurangi biaya modal, meningkatkan kepercayaan investor dan juga meningkatkan peringkat perusahaan, yang menunjukkan bahwa perusahaan memiliki kemampuan untuk membayar hutang dalam kondisi yang memungkinkan Fraser \& Simkins (2007). Baxter et al.(2013) menyarankan bahwa program manajemen risiko berkualitas tinggi meningkatkan kinerja operasi dan 
menambah nilai bagi perusahaan. Hoyt \& Lienberg (2011) menyarankan bahwa manajemen risiko dan nilai bisnis memiliki korelasi positif. Gates et al.(2012) menyatakan bahwa perusahaan akan mengambil keputusan yang lebih baik dengan menerapkan proses manajemen risiko. Manajemen risiko memberikan pemahaman kepada perusahaan untuk mengelola risiko di seluruh unit bisnis dan membantu mereka untuk meningkatkan pengembalian modal dan efisiensi modal Meulbroek (2002). Nocco \& Stulz (2006) menemukan bahwa perusahaan dapat memperoleh keunggulan kompetitif jangka panjang karena manajemen risiko memberikan manfaat tingkat mikro kepada perusahaan dengan menentukan tanggung jawab pengambilan risiko pada tingkat yang lebih rendah misalnya bagaimana dan oleh siapa risiko itu dimiliki.

Beberapa peneliti menemukan hasil yang beragam atau merugikan mengenai hubungan antara manajemen risiko dan nilai perusahaan. McShane et al.(2011) menyelidiki efek manajemen risiko pada nilai perusahaan dan menemukan bukti hubungan positif antara peningkatan tingkat kemampuan ERM dan nilai perusahaan, tetapi tidak ada nilai perusahaan tambahan untuk perusahaan yang mencapai peringkat manajemen risiko yang tinggi. Lebih lanjut, Lin et al. (2011) melakukan penelitian teoritis dan menguji pengaruh manajemen pada nilai perusahaan dan menemukan bahwa implementasi manajemen risiko menunjukkan korelasi negatif yang signifikan dengan nilai perusahaan. Penelitian yang dilakukan oleh Sayilir \& Farhan (2017) menunjukkan tidak ada hubungan yang signifikan antara nilai perusahaan dan manajemen risiko, hal tersebut dapat terjadi karena efek manajemen risiko belum tercermin pada nilai perusahaan. Sebagian besar perusahaan telah menerapkan praktik menajemen risiko untuk periode waktu yang singkat namun, tetap membutuhkan waktu lama untuk praktik manajemen risiko yang tercermin pada kinerja perusahaan dan nilai perusahaan. Hasil penelitian Anton (2018) juga menunjukkan manajemen risiko tidak mempengaruhi nilai perusahaan secara signifikan. Tidak signifikannya hasil penelitian Sayilir \& Farhan, (2017) dan Anton (2018) dapat terjadi karena penelitian tersebut dilakukan pada saat krisis global dunia 2008-2011.

\subsection{Pengungkapan Manajemen Risiko}

Pengungkapan manajemen risiko merupakan pengungkapan atas risikorisiko yang dikelola perusahaan dalam mengendalikan risiko yang akan datang. Pengungkapan manajemen risiko penting karena membantu stakeholder dalam mendapatkan informasi yang diperlukan untuk memahami profil risiko dan bagaimana manajemen mengelola risiko. Informasi megenai manajemen risiko terdapat pada laporan keuangan bank. Pada teori signaling dikatakan informasi yang baik diperlukan oleh investor di pasar modal sebagai alat analisis untuk mengambil keputusan investasi. Informasi yang dipublikasikan sebagai suatu pengumuman akan memberikan sinyal bagi investor dalam pengambilan keputusan investasi. Peraturan OJK No. 6/PJOK.03/2015 tentang transparansi dan publikasi laporan bank menyatakan bahwa bank wajib menyusun, mengumumkan dan menyampaikan laporan publikasi dalam rangka transparansi kondisi keuangan dan kinerja bank. Informasi tersebut berupa informasi kuantitatif dan kualitatif yang disediakan dapat mempermudah pengguna informasi dalam menilai kondisi keuangan, kinerja, profil risiko dan penerapan manajemen risiko, aktivitas bisnis bank, penetapan tingkat suku bunga, serta kondisi keuangan entitas induk, entitas anak, perusahaan terelasi dan pihak terkait bank. Pada Peraturan Bank Indonesia 
No.13/1/PBI/2011, terdapat 4 pilar yang merupakan penerapan manajemen risiko. Yaitu, terdiri dari pengawasan aktif Dewan Komisaris dan Direksi, kecukupan kebijakan, prosedur dan penetapan limit, proses manajemen risiko dan sistem informasi manajemen risiko dan sistem pengendalian internal. Pilar penerapan manajemen risiko berlaku pada seluruh jenis risiko yang terdiri dari 8 jenis risiko yaitu :

1. Risiko kredit

2. Risiko pasar

3. Risiko likuiditas

4. Risiko operasional

5. Risiko kepatuhan

6. Risiko hukum

7. Risiko stratejik

8. Risiko reputasi

COSO (Committee of Sponsoring

Organizations of the Tredway Commission) merupakan suatu inisiatif dari sektor swasta yang dibentuk pada tahun 1985. Tujuan utamanya adalah untuk mengidentifikasi faktor-faktor yang menyebabkan penggelapan laporan keuangan dan membuat rekomendasi untuk mengurangi kejadian tersebut. COSO telah menyusun suatu definisi umum untuk pengendalian, standar, dan kriteria internal yang dapat digunakan perusahaan untuk menilai sistem pengendalian perusahaan. Prinsip dasar yang ditanamkan COSO ERM adalah semua bagian di dalam perusahaan memiliki tanggung jawab terhadap ERM.

\subsection{Kerangka Risiko Manajemen Perusahaan}

Terdapat banyak standar mengenai kerangka ERM, salah satunya yang dimiliki oleh COSO Enterprise Risk Management. Dalam kerangka manajemen risikonya, COSO ERM menuntut perusahaan untuk dapat menentukan terlebih dahulu sasaran perusahaannya, yang terdiri dari empat kategori yaitu :
1. Strategi : sasaran yang mendukung dan selaras dengan misi perusahaan

2. Operasi : efektivitas dan efesiensi dari penggunaan sumber daya perusahaan

3. Pelaporan : keterpercayaan dari pelaporan

4. Pemenuhan : pemenuhan terhadap hukum dan regulasi yang berlaku

COSO Enterprise Risk

Management - Integrating with Strategy and Performance (2017) terdiri dari 5 komponen yaitu Governance and Culture, Strategy and Objective Setting, Performance, Review and Revision, dan Communication and Reporting. Dari 5 komponen tersebut terdapat 20 prinsip utama sebagai berikut :

1. Tata Kelola dan Budaya Organisasi terdiri dari 5 prinsip :

a. Pengawasan Risiko Dewan

b. Menetapkan Struktur Operasi

c. Menentukan Budaya yang Diinginkan

d. Menunjukkan Komitmen terhadap Nilai-Nilai Inti

e. Menarik, Mengembangkan, dan Mempertahankan Individu

2. Strategi dan Penetapan Tujuan terdiri dari 4 prinsip :

a. Menganalisis Konteks Bisnis

b. Mendefinisikan Risk Appetite

c. Mengevaluasi Strategi Alternatif

d. Merumuskan Tujuan Bisnis

3. Kinerja terdiri dari 5 prinsip :

a. Identifikasi Risiko

b. Menilai Tingkat Keparahan Risiko

c. Prioritaskan Risiko

d. Mengimplementasikan Respons Risiko

e. Mengembangkan Pandangan Portofolio

4. Penelaahan dan Revisi terdiri dari 3 prinsip :

a. Menilai Perubahan Besar

b. Tinjauan Risiko dan Kinerja

c. Mengejar Peningkatan Manajemen Risiko Perusahaan

5. Informasi, komunikasi dan laporan terdiri dari 3 prinsip : 
a. Memanfaatkan Sistem Informasi

b. Mengkomunikasikan Informasi Risiko

c. Laporan tentang Risiko, Budaya, dan Kinerja

\subsection{Pengembangan Hipotesis}

Pengaruh pengungkapan manajemen risiko terhadap profitabilitas

Pengungkapan manajemen risiko yang relevan menggambarkan suatu perusahaan bisa mengatasi risiko yang dihadapi oleh perusahaan. Kemampuan perusahaan dalam mengelola risikorisikonya merupakan salah satu faktor meningkatnya profit perusahaan Ansori (2018). Olayinka et al.(2017) menemukan pengaruh positif yang signifikan antara manajemen risiko terhadap profitabilitas di sektor keuangan Nigeria. Mereka menggunakan Value at Risk sebagai ukuran manajemen risiko. Hasil penelitiannya menunjukkan bahwa organisasi dapat mengendalikan risk appetite yang selalu ada dampak positif pada kinerja keuangan. Kerangka ERM dapat memberikan manfaat tidak hanya perusahaan melainkan pihak lain yang berkepentingan. Teori stakeholder menunjukkan bahwa, jika perusahaan mendapat dukungan oleh stakeholder maka perusahaan tersebut diakui keberadaannya. Pengungkapan manajemen risiko yang didukung oleh stakeholder akan menghasilkan kenaikan labanya dengan cara mengelola peluang dan risiko perusahaan dengan baik.

Sejalan dengan teori stakeholder kerangka ERM memberikan manfaat tidak hanya pada perusahaan saja melainkan pemangku kepentingan (stakeholder). Sejalan dengan penelitian yang dilakukan oleh Cahyaningtyas \& Sasanti (2019) menunjukkan penerapan manajemen risiko berpengaruh positif terhadap profitabilitas. Penerapan manajemen risiko yang diproksikan NIM menunjukkan kemampuan manajemen bank dalam mengelola aktiva produktifnya untuk menghasilkan pendapatan bunga bersih. Semakin besar pendapatan bunga yang dikelola bank maka semakin kecil kemungkinan bank bermasalah dan pada akhirnya meningkatkan profitabilitas bank. Berdasarkan hal tersebut di atas maka kami berhipotesis bahwa:

H1 : Pengungkapan manajemen risiko berpengaruh positif terhadap profitabilitas

\section{Pengaruh pengungkapan manajemen risiko terhadap nilai perusahaan}

Teori sinyal menggambarkan bagaimana semestinya suatu perusahaan memberikan indikasi kepada para pengguna laporan keuangan. Sinyal positif perusahaan diperlukan agar para stakeholder memberikan dukungan kepada perusahaan. Pengungkapan manajemen risiko yang relevan menggambarkan suatu perusahaan bisa mengatasi risiko yang dihadapi oleh perusahaan. Azim \& Abdelmoniem (2015) menemukan bahwa pengungkapan risiko akan mengurangi eksposur risiko dengan mengelola risiko pasar nilai perusahaan juga akan meningkat. Di Indonesia penerapan manajemen risiko masih sedikit akan tetapi positif dan signifikan Iswajuni et al. (2018). Luasnya informasi risiko manajemen secara sukarela yang dipublikasikan oleh perusahaan direspon positif oleh pasar. Pasar percaya bahwa pengungkapan manajemen risiko dapat digunakan sebagai salah satu informasi yang relevan dalam mengidentifikasi masa depan dan keberlangsungan perusahaan Devi et al. (2017).

Manajemen risiko perusahaan
dapat mengurangi biaya kesulitan keuangan, meningkatkan penghindaran risiko manajerial, memitigasi pembayaran pajak yang diharapkan, menyelesaikan masalah kekurangan investasi dan memberikan kepercayaan bagi bisnis untuk melakukan proyek investasi baru. Pengungkapan manajemen risiko dapat 
memberikan sinyal positif bagi para stakeholder. Sejalan dengan teori sinyal dan penelitian terdahulu, maka kami berhipotesis bahwa:

$\mathrm{H} 2$ : Pengungkapan manajemen risiko berpengaruh positif terhadap nilai perusahaan

\section{Pengaruh profitabilitas terhadap nilai perusahaan}

Profitabilitas yang merupakan salah satu sinyal perusahaan. Jika informasi laba perusahaan meningkat maka berita tersebut positif (goodnews), sebaliknya jika informasi laba perusahaan menurun maupun mengalami kerugian maka berita tersebut negatif (badnews). Para investor yang melihat informasi tersebut akan merespon dan membuat naiknya harga saham. Hasil penelitian yang dilakukan oleh Sabrin et al. (2016), menunjukkan profitabilitas berpengaruh positif terhadap nilai perusahaan. Profitabilitas dipertimbangkan oleh investor dan pemegang saham karena berkaitan dengan harga saham dan dividen yang diterima. Semakin meningkat laba perusahaan maka harga saham akan naik dan semakin besar deviden yang dibagikan.

Hubungan antara profitabilitas dan nilai perusahaan menjelaskan bahwa laporan keuangan dan pengungkapan yang penting dan bermakna bagi manajemen sebagai sarana mengkomunikasikan tata kelola dan kinerja perusahaan kepada stakeholder. Profitabilitas yang tinggi mencerminkan kemampuan perusahaan untuk menghasilkan pengembalian yang tinggi untuk pemegang saham. Penelitian yang dilakukan Tui et al. (2017) menemukan pengaruh signifikan positif antara profitabilitas terhadap nilai perusahaan. Tinggiya profitabilitas perusahaan dapat menunjukkan prospek yang lebih baik kepada investor sehingga investor akan tertarik pada perusahaan yang memiliki profitabilitas tinggi. Sejalan dengan teori sinyal, teori stakholder dan penelitian terdahulu maka kami berhipotesis bahwA: H3 : Profitabilitas berpengaruh positif terhadap nilai perusahaan

\section{Pengaruh tidak langsung pengungkapan manajemen risiko terhadap nilai perusahaan melalui profitabilitas}

Teori sinyal mengatakan bahwa risiko dan kinerja keuangan yang baik merupakan bagian dari perusahaan yang dapat menjadi sinyal bagi investor dalam pengambilan keputusan. Manajemen risiko memiliki manfaat utama untuk manangani risiko secara efektif. Penerapan manajemen risiko yang baik dapat menjadi peluang bagi perusahaan untuk memaksimalkan laba. Kinerja keuangan telah diteliti oleh beberapa peneliti Solikhah \& Hariyati (2018) dan Agustina (2016) untuk memediasi hubungan manajemen risiko dan nilai perusahaan. Profitabilitas yang lebih tinggi mencerminkan jaminan pengembalian yang lebih tinggi. Nugraha (2013), mendukung bahwa secara positif memengaruhi nilai dan kinerja keuangan perusahaan. Kinerja keuangan dianggap mampu dalam memediasi manajemen risiko terhadap nilai perusahaan. Pasar memberikan penilaian yang lebih tinggi terhadap perusahaan yang memiliki kinerja keuangan yang tinggi dibandingkan dengan kinerja keuangan yang buruk. Kinerja tersebut tentunya mendapat dukungan dari stakeholder dalam mengelola risiko perusahaan dengan baik. Berdasarkan asumsi ini, perusahaan yang melakukan penerapan manajemen risiko dengan baik dan didukung dengan profitabilitas yang tinggi maka hal tersebut dapat meningkatkan nilai perusahaan. Berdasarkan hal tersebut diatas maka kami berhipotesis bahwa :

H4 : Pengungkapan manajemen risiko berpengaruh terhadap nilai perusahaan melalui profitabilitas 


\section{Metodologi Penelitian}

\subsection{Pemilihan dan Pengumpulan Data}

Populasi yang digunakan dalam penelitian ini adalah seluruh perbankan yang terdaftar di Bursa Efek Indonesia pada periode 2016 sampai 2018 (terdapat pada situs resmi www.idx.co.id ) sebanyak 46 entitas. Metode pengambilan sampel dilakukan dengan metode purposive sampling. Sampel yang dipilih adalah sampel yang memenuhi kriteria antara lain :

1. Entitas perbankan yang terdaftar di Bursa Efek Indonesia pada periode 2016-2018

2. Entitas perbankan yang mempublikasikan laporan keuangan dan/atau annual report pada periode 2016-2018 secara lengkap dan berturut-turut.

3. Laporan keuangan yang tidak ada data pencilan (outlier)

Tabel 1 menunjukkan proses pemilihan sampel. Dari 46 entitas perbankan terdapat 10 entitas yang tidak lengkap dalam laporan keuangannya secara berturut-turut. Total sampel dalam tiga tahun adalah 108 sampel. Terdapat 6 data pencilan dalam seluruh sampel sehingga sampel akhir penelitian adalah 102 sampel. Data pencilan (outlier) telah dihilangkan menggunakan teknik trimming. Kriteria pemilihan sampel terdapat pada tabel 1.

Tabel 1. Kriteria Pemilihan Sampel

\begin{tabular}{clc}
\hline No & \multicolumn{1}{c}{ Kriteria } & Banyak \\
\hline 1 & $\begin{array}{l}\text { Entitas perbankan } \\
\text { yang secara berturut- }\end{array}$ & 46 \\
& \\
& $\begin{array}{l}\text { turut di BEI pada } \\
\text { periode 2016-2018 }\end{array}$ & \\
\hline 2 & $\begin{array}{l}\text { Entitas perbankan } \\
\text { yang tidak lengkap }\end{array}$ & $(10)$ \\
& mempublikasikan \\
& laporan keuangan & \\
\hline & $\begin{array}{l}\text { Analisis dalam 3 } \\
\text { tahun }\end{array}$ & 108 \\
& & \\
\hline
\end{tabular}

\begin{tabular}{lll}
\hline 3 & $\begin{array}{l}\text { Laporan keuangan } \\
\text { yang memiliki data } \\
\text { pencilan }\end{array}$ & (6) \\
\hline Jumlah sampel akhir & 102 \\
\hline
\end{tabular}

Sumber : idx.co.id (data diolah)

Pengumpulan data dalam penelitian ini adalah dengan menggunakan data sekunder laporan keuangan yang terdapat di Bursa Efek Indonesia periode 20162018. Waktu penelitian di mulai pada bulan April sampai dengan bulan Juni 2020. Data dianalisis menggunakan analisis deskriptif, regresi linier dan analisis jalur.

\subsection{Model Penelitian}

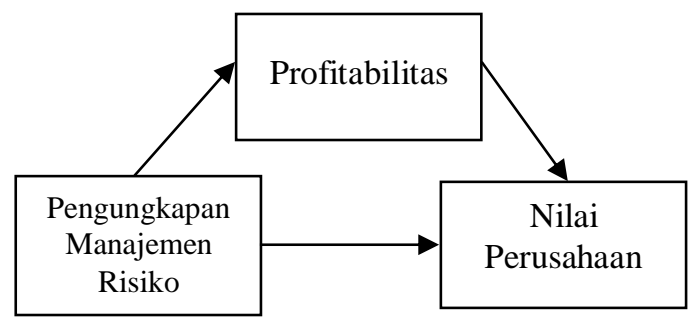

Gambar 1 Model Penelitian

Model analisis jalur digunakan untuk menganalisis pola hubungan antar variabel dengan tujuan untuk mengetahui pengaruh langsung maupun tidak langsung variabel independen terhadap variabel dependen melalui variabel intervening. Uji sobel digunakan untuk pengujian hipotesis mediasi. Adapun persamaan kedua model sebagai berikut :

1. $\mathrm{ROA}=\beta_{0}+\beta_{\mathrm{Y} 1 \mathrm{X} 1} \mathrm{RMD}+\mathrm{e}_{\mathrm{t}}$

2. $\mathrm{PBV}=\beta_{0}+\beta_{\mathrm{Y} 2 \mathrm{X} 1} \mathrm{RMD}+\beta_{\mathrm{Y} 2 \mathrm{Y} 1} \mathrm{ROA}+\mathrm{e}_{\mathrm{t}}$ Keterangan :

ROA = Profitabilitas

PBV = Nilai Perusahaan

RMD $=$ Pengungkapan Manajemen

Risiko

$\beta_{\mathrm{Y} 1 \mathrm{X} 1}=$ Koefisien Jalur $\mathrm{X}_{1}$ ke $\mathrm{Y}_{1}$

$\beta_{\mathrm{Y} 2 \mathrm{X} 1}=$ Koefisien Jalur $\mathrm{X}_{1}$ ke $\mathrm{Y}_{2}$

$\beta_{\mathrm{Y} 2 \mathrm{Y} 1}=$ Koefisien Jalur $\mathrm{Y}_{1}$ ke $\mathrm{Y}_{2}$

\subsection{Operasional Variabel}




\section{Variabel Dependen}

Variabel dependen dalam penelitian ini adalah nilai perusahaan. Nilai perusahaan merupakan nilai pasar yang mampu memberikan kemakmuran untuk pemagang saham. Nilai perusahaan diukur dengan PBV (price book value) yaitu membandingkan harga saham terhadap nilai buku per lembar saham Brigham \& Houston (2014). PBV mencerminkan rasio yang mengukur nilai pasar keuangan kepada manajemen dan organisasi perusahaan.

\section{Variabel Independen}

Variabel independen dalam penelitian ini adalah pengungkapan manajemen risiko. Pengungkapan manajemen risiko diartikan sebagai tingkat pengungkapan atas risiko-risiko yang dikelola perusahaan. Pengungkapan manajemen risiko diukur dengan ERM framework yang dikeluarkan oleh COSO, yang terdiri dari 20 item pengungkapan. Metode pengumpulan data yang digunakan untuk menganalisis pengungkapan manajemen risiko adalah content analysis. Skala dikonomi tidak tertimbang digunakan dalam pemberian skor untuk setiap item pengungkapan yang dilakukan perusahaan dalam annual report. Setiap pengungkapan suatu item akan diberi nilai 1 dan 0 jika item tidak diungkapkan, kemudian skor dari setiap item akan dijumlahkan untuk memperoleh total skor pengungkapan manajemen risiko dan total skor tersebut akan dibandingkan dengan total item (20) pengungkapan.

\section{Variabel Intervening}

Variabel intervening dalam penelitian ini adalah profitabilitas. Profitabilitas merupakan rasio untuk menilai kemampuan perusahaan dalam memperoleh keuntungan Baxter et al. (2013). Profitabilitas diukur dengan ROA (Return on Assets). Rasio ROA mencerminkan kemampuan perusahaan menghasilkan laba dari penggunaan seluruh aset yang dimiliki. Rasio ROA dipilih untuk mengukur profitabilitas bank karena Bank Indonesia sebagai pembina dan pengawas perbankan lebih mengutamakan nilai profitabilitas suatu bank yang dikur dengan aset yang dananya sebagian besar dari dana simpanan masyarakat. Semakin besar ROA suatu bank maka semakin besar pula tingkat keuntungan yang dicapai bank.

\section{HASIL DAN PEMBAHASAN}

\subsection{Hasil}

Analisis statistik deskriptif dilakukan untuk menentukan deskripsi masing-masing variabel penelitian. Analisis yang digunakan dalam penelitian ini mencakup nilai minimum, maksimum, rata-rata dan standar deviasi. Hasil uji statistik deskriptif dapat dilihat pada Tabel 2 di bawah ini:

Tabel 2. Hasil Statistik Deskriptif Penelitian

\begin{tabular}{|l|c|c|c|c|c|}
\hline \multicolumn{7}{|c|}{ Descriptive Statistics } \\
\hline & $\mathrm{N}$ & Min & Max & Mean & $\begin{array}{c}\text { Std. } \\
\text { Dev }\end{array}$ \\
\hline RMD & 102 &, 50 &, 90 &, 7299 &, 1196 \\
\hline ROA & 102 & - & 4,00 & 1,465 & 1,164 \\
\hline PBV & 102 &, 15 & 3,40 & 1,360 &, 7900 \\
\hline $\begin{array}{l}\text { Valid } \\
\text { N }\end{array}$ & 102 & & & & \\
\hline
\end{tabular}

Sumber : Output SPSS 23, 2020

Tabel 2 menunjukkan bahwa nilai rata-rata semua variabel cukup baik. Deviasi standar semua variabel lebih rendah dari rata-rata. Ini menunjukkan bahwa variasi distribusi dari nilai perusahaan cenderung sama satu sama lain.

\subsubsection{Hasil Uji Asumsi Klasik Uji Normalitas}

Uji normalitas dengan

Kolmogorov-Smirnov Test. Tabel Kolmogorov Smirnov didapat data Asym. Sig (2-tailed) untuk semua variabel $>0,05$ 
sehingga model regresi memenuhi asumsi normalitas.

Tabel 3. Hasil Uji Normalitas

\begin{tabular}{lcc}
\hline & $\begin{array}{c}\text { Asym. Sig } \\
\text { (2-tailed) }\end{array}$ & Ket \\
\hline RMD $\rightarrow$ ROA & 0,071 & $\begin{array}{c}\text { Distribusi } \\
\text { Normal } \\
\text { Distribusi } \\
\text { Normal }\end{array}$ \\
\hline
\end{tabular}

Sumber : Output SPSS 23, 2020

Dari tabel 4 dapat dilihat seluruh data analisis berdistribusi normal, karena nilai signifikan yang dihasilkan lebih besar dari $5 \%$ atau 0,05 .

\section{Analisis Regresi dengan Variabel} Intervening

\begin{tabular}{|c|c|c|c|c|c|c|}
\hline & Tabel & Hasil An & lisis $\mathrm{Re}$ & resi Mc & el I & \\
\hline & \multirow{2}{*}{ Model } & \multicolumn{2}{|c|}{$\begin{array}{l}\text { Unstandardized } \\
\text { Coefficients }\end{array}$} & \multirow{2}{*}{$\begin{array}{l}\text { Stand. } \\
\text { Coef. } \\
\text { Beta }\end{array}$} & \multirow{2}{*}{$\mathrm{t}$} & \multirow{2}{*}{ Sig. } \\
\hline & & B & $\begin{array}{l}\text { Std. } \\
\text { Error }\end{array}$ & & & \\
\hline \multirow[t]{2}{*}{1} & (Constant) & $-4,386$ & ,408 & & $-10,75$ &, 000 \\
\hline & RMD & 8,016 & ,551 & 824 & 14,53 & ,000 \\
\hline \multicolumn{7}{|c|}{ Dependent Variable: ROA } \\
\hline
\end{tabular}

Sumber : Output SPSS 23, 2020

Tabel 4 merupakan hasil linier regresi linier sederhana dari model I. Pengungkapan manajemen risiko memiliki nilai koefisien sebesar 8,016 menunjukkan bahwa variabel pengungkapan manajemen perusahaan meningkat satu satuan maka variabel profitabilitas akan mengalami peningkatan sebesar 8,016 satuan dengan ketentuan variabel lain konstan.

\begin{tabular}{|c|c|c|c|c|c|c|}
\hline \multicolumn{7}{|c|}{ Tabel 5. Hasil Analisis Regresi Model II } \\
\hline & \multirow[t]{2}{*}{ Model } & \multicolumn{2}{|c|}{$\begin{array}{c}\text { Unstandardiz } \\
\text { ed } \\
\text { Coefficients }\end{array}$} & \multirow{2}{*}{ 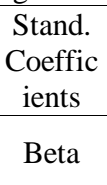 } & \multirow[t]{2}{*}{$\mathrm{t}$} & \multirow[t]{2}{*}{ Sig. } \\
\hline & & B & $\begin{array}{l}\text { Std. } \\
\text { Error }\end{array}$ & & & \\
\hline \multirow[t]{3}{*}{2} & (Constant) &,- 949 & 671 & & $-1,414$ &, 160 \\
\hline & RMD & 3,463 & 1,09 & ,524 & 3,177 & ,002 \\
\hline & ROA &,- 149 &, 112 &,- 220 & $-1,332$ & ,186 \\
\hline & endent $\mathrm{Va}$ & le: $\mathrm{PE}$ & & & & \\
\hline
\end{tabular}

Sumber : Output SPSS 23, 2020

Tabel 5 merupakan hasil linier regresi linier berganda dari model II. Pengungkapan manajemen risiko memiliki nilai koefisien sebesar 3,463 menunjukkan bahwa variabel pengungkapan manajemen risiko meningkat satu satuan maka variabel nilai perusahaan akan mengalami peningkatan sebesar 3,463 satuan dengan ketentuan variabel lain konstan. Sedangkan profitabilitas memiliki nilai koefisien sebesar -0,149 menunjukkan bahwa variabel profitabilitas meningkat satu satuan maka variabel nilai perusahaan akan mengalami penurunan sebesar 0,149 satuan dengan ketentuan variabel lain konstan.

\subsubsection{Analisis Jalur}

Analisis jalur digunakan untuk menguji pengaruh variabel intervening (mediasi). Analisis jalur merupakan perluasan dari analisisi regresi untuk menaksir hubungan tidak langsung antar satu variabel melalui variabel mediasi. Dari nilai-nilai yang dihasilkan pada kedua model regresi yang dilakukan, maka diperoleh diagram jalur sebagai

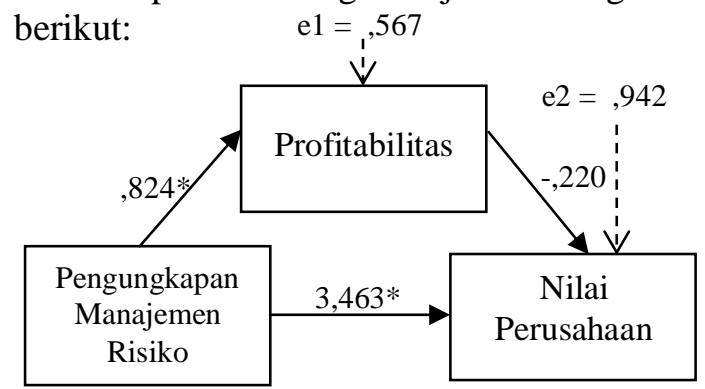

Gambar 2 Diagram Jalur Model 
Tabel 6. Residual coefficient Analisis Jalur

\begin{tabular}{|c|c|c|c|}
\hline Model & Regresi & $\begin{array}{c}R \\
\text { Square }\end{array}$ & $\begin{array}{c}\text { Residual } \\
\text { coefficient }\end{array}$ \\
\hline 1 & RMD $\rightarrow$ ROA &, 679 & $\sqrt{ } 1-, 679=, 567$ \\
\hline 2 & $\begin{array}{l}\text { RMD,ROA } \rightarrow \\
\text { PBV }\end{array}$ &, 133 & $\sqrt{ } 1-, 113=, 942$ \\
\hline
\end{tabular}

Sumber : Output SPSS 23, 2020

Koefisien jalur pengungkapan manajemen risiko dan profitabilitas sebesar 0,824. Koefisien jalur pengungkapan manajemen risiko dan nilai perusahaan sebesar 3,463. Koefisien jalur profitabilitas dan nilai perusahaan sebesar -0,220. Residual coefficient dari persamaan regresi pertama 0,567 dan Residual coefficient dari persamaan regresi kedua 0,942 .

\subsubsection{Sobel Test}

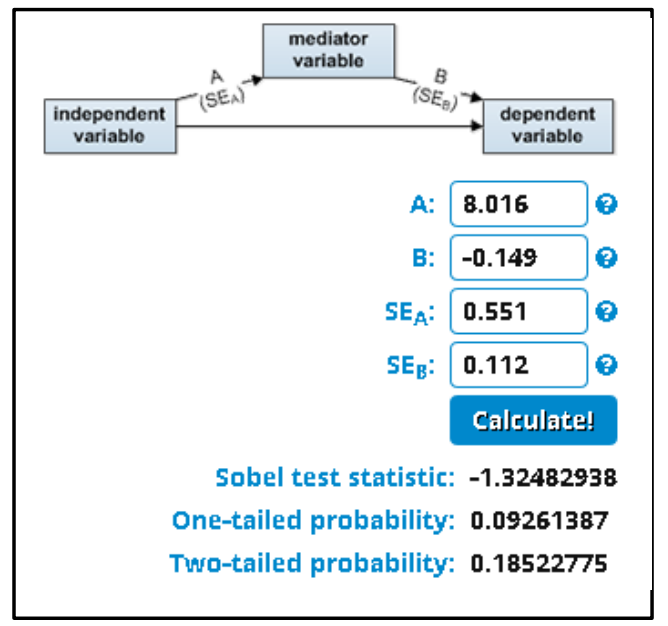

Gambar 3 Hasil Sobel Test

Uji sobel digunakan dalam melakukan pengujian hipotesis mediasi ini. Uji sobel dengan cara menguji kekuatan pengaruh tidak langsung pengungkapan manajemen risiko terhadap nilai perusahaan melalui profitabilitas. Hasil tes sobel pada gambar 3 menunjukkan nilai signifikansi dihasilkan sebesar 0,18522775 > 0,05. Disimpulkan bahwa profitabilitas tidak memediasi hubungan antara pengungkapan manajemen risiko dengan nilai perusahaan.

\subsection{Pembahasan}

\subsubsection{Pengaruh pengungkapan mana- jemen risiko terhadap profitabilitas}

Tabel 7. Hasil Penelitian

\begin{tabular}{|c|c|c|c|c|c|l|}
\hline Y & $\mathrm{X}$ & $\mathrm{H}$ & $\begin{array}{c}\text { Koef } \\
\text { jalur }\end{array}$ & $\mathrm{t}$ & $\mathrm{Sig}$ & Hasil \\
\hline ROA & RMD & H1 &, 824 & 14,539 &, 000 & diterima \\
\hline PBV & RMD & H2 &, 524 & 3,177 &, 002 & diterima \\
\hline PBV & ROA & H3 &,- 220 & $-1,332$ &, 186 & ditolak \\
\hline
\end{tabular}

Sumber : Output SPSS 23, 2020

Tabel 7 menunjukkan bahwa pengungkapan manajemen risiko memiliki pengaruh positif signifikan terhadap profitabilitas sehingga hipotesis pertama dalam penelitian ini diterima. Risiko-risiko serta peluang dalam penelitian ini mampu dikelola dengan baik oleh perusahaan sehingga memberikan efek positif pada peningkatan profitabilitas. Seperti tanggung jawab, pengawasan serta penerapan yang baik dilakukan oleh Board of Directors dengan memperhitungkan risk appetite. Perbankan memprioritaskan risiko untuk memilih respon mana yang tepat terhadap risiko tersebut. Perbankan juga memanfaatkan sistem informasi dan teknologi untuk mendukung perusahaan dalam mencari peluang serta risiko perusahaan. Hal tersebut diatas merupakan pengungkapan manajemen risiko yang membuat laba perusahaan meningkat.

Teori stakeholder mengatakan dalam aktivitasnya perusahaan tidak lepas dari kepentingan lainnya. Kerjasama antara pihak internal dan eksternal serta kepatuhan terhadap regulasi, membuat semakin baiknya manajemen risiko perusahaan serta meningkatkan kinerja keuangannya. Sejalan dengan penelitian Olayinka et al. (2017) dan Cahyaningtyas \& Sasanti (2019) pengungkapan manajemen risiko dan profitabilitas berpengaruh positif signifikan. Hasil ini menunjukkan kerangka COSO Enterprise Risk Management - Integrating with Strategy and Performance yang 
diungkapkan pada sektor perbankan di Indonesia secara keseluruhan berpengaruh terhadap laba perusahaan. Penerapan COSO framework 2017 disertai pengungkapan yang detail, lengkap serta akurat menunjukkan kemampuan perusahaan dalam mengelola risikonya. Dalam penelitian ini perbankan cukup baik mengenai respon yang dihadapi oleh bank atas risikonya. Semakin baiknya pengungkapan manajemen risiko bank maka semakin baik pula kinerja keuangan perusahaan, sebaliknya jika bank tersebut buruk dalam menerapkan serta mengungkapkan manajemen risiko akan mendapatkan umpan balik yang buruk terhadap kinerja keuangan perusahaan.

\subsubsection{Pengaruh pengungkapan mana- jemen risiko terhadap nilai perusahaan}

Tabel 7 menunjukkan bahwa pengungkapan manajemen risiko memiliki pengaruh positif signifikan terhadap nilai perusahaan. Hipotesis kedua dalam penelitian ini diterima. Pengungkapan manajemen risiko pada sektor perbankan menunjukkan pengawasan dewan direksi, nilai-nilai perusahaan serta pengembangan sumber daya manusia sejalan dengan strategi dan tujuan perusahaan. Selain itu, kinerja penilaian risiko menunjukkan respon risiko yang positif dalam memutuskan langkah selanjutnya. Hal ini membuat informasi (goodnews) yang diterima oleh investor menjadi sinyal positif. Pasar percaya bahwa pengungkapan manajemen risiko dapat digunakan sebagai salah satu informasi yang relevan dalam mengidentifikasi masa depan dan keberlangsungan perusahaan. Sejalan dengan penelitian Azim \& Abdelmoniem (2015); Devi et al. (2017) dan Iswajuni et al. (2018) menunjukkan bahwa pengungkapan manajemen dan nilai perusahaan berpengaruh positif dan signifikan terhadap nilai perusahaan.
Lebih lanjut, hasil ini menunjukkan kerangka COSO Enterprise Risk Management - Integrating with Strategy and Performance yang diungkapkan pada sektor perbankan di Indonesia secara keseluruhan berpengaruh terhadap nilai perusahaan. Penerapan COSO framework 2017 disertai luasnya pengungkapan yang relevan menunjukkan kemampuan perusahaan dalam mengelola risikonya. Semakin baiknya pengungkapan manajemen risiko bank maka semakin baik pula nilai perusahaan, sebaliknya jika bank tersebut buruk dalam menerapkan serta mengungkapkan manajemen risiko maka nilai perusahaan juga semakin buruk.

\subsubsection{Pengaruh profitabilitas terhadap nilai perusahaan}

Tabel 7 menunjukkan bahwa profitabilitas memiliki pengaruh negatif dan tidak signifikan terhadap nilai perusahaan. Hipotesis ketiga dalam penelitian ini ditolak. Berbeda dengan penelitian yang dilakukan oleh Sabrin et al.(2016) dan Tui et al.(2017) menunjukkan bahwa profitabilitas memiliki pengaruh yang positif signifikan terhadap nilai perusahaan. Namun demikian, hasil penelitian ini sejalan dengan Faster \& Simkins (2007) dan Thaib \& Dewantoro (2017) yang menunjukkan bahwa profitabilitas berpengaruh negatif dan tidak signifikan. Hal ini dikarenakan LPS mengungkapkan dalam tiga tahun terakhir tingkat profitabilitas perbankan terus menurun. Salah satu penyebab menurunnya profitabilitas bank akibat margin bunga yang lemah karena tren penurunan bunga kredit. Ketua Dewan Komisiener LPS Halim Alamsyah mengatakan "profitabilitas bank itu cenderung turun karena margin dari penyaluran kredit yang lemah, ditambah masih tingginya rasio kredit bermasalah. Juga ada regulasi ketat dari OJK dan Bank Indonesia”. Disisi lain 
rata-rata nilai perusahaan pada perbankan di Indonesia memiliki nilai yang stagnan.

\subsubsection{Pengaruh tidak langsung pengungkapan manajemen risiko terhadap nilai perusahaan melalui profitabilitas}

Dari pengujian sobel yang dilakukan, pengaruh mediasi yang dihasilkan tidak signifikan yang berarti tidak ada pengaruh mediasi. Hipotesis empat dalam penelitian ini ditolak. Profitabilitas tidak memediasi hubungan pengungkapan manajemen risiko dengan nilai perusahaan. Penelitian ini sejalan dengan Solikhah \& Hariyati (2018) dan Agustina (2016). Profitabiltas merupakan bukan syarat naiknya nilai perusahaan dalam hubungannya dengan pengungkapan manajemen risiko. Hal ini menunjukkan besar kecilnya profitabilitas perusahaan bukan menjadi penentu perusahaan dalam mengelola aktivitas manajemen risiko. Teori agensi mengatakan profitabilitas harus memiliki kapasitas untuk memediasi antara pengungkapan manajemen risiko dan nilai perusahaan. Proksi profitabilitas dalam penelitian ini belum mencerminkan perubahan yang signifikan dalam aktivitas manajemen risiko pada perbankan Indonesia. Dengan demikian, profitabilitas tidak memiliki kapasitas untuk memediasi pengaruh pengungkapan manajemen risiko pada nilai perusahaan.

\section{KESIMPULAN}

Pengaruh pengungkapan manajemen risiko terhadap profitabilitas memiliki hubungan yang positif signifikan, hal ini menunjukkan bahwa pengungkapan manajemen risiko yang dilakukan entitas perbankan Indonesia dapat memberikan kontribusi yang positif terhadap profitabilitas. Kerangka COSO Enterprise Risk Management Integrating with Strategy and Performance yang diungkapkan pada sektor perbankan di Indonesia secara keseluruhan berpengaruh terhadap laba perusahaan. Penerapan COSO framework 2017 disertai pengungkapan yang detail, lengkap serta akurat menunjukkan kemampuan perusahaan dalam mengelola risikonya. Pengaruh pengungkapan manajemen risiko terhadap nilai perusahaan juga memiliki hubungan yang positif signifikan. Peran dan tanggung jawab dewan direksi dalam menjalankan strategi bisnisnya diimbangi pengaplikasian teknologi informasi perbankan di respon baik oleh pasar. Pasar percaya bahwa pengungkapan manajemen risiko dapat digunakan sebagai salah satu informasi yang relevan dalam mengidentifikasi masa depan dan keberlangsungan perusahaan.

Komponen yang terdiri dari tata kelola dan budaya organisasi, strategi dan penetapan tujuan, kinerja, penelaah dan revisi, informasi, komunikasi dan laporan secara keseluruhan diungkapkan pada annual report perbankan. Komponen manajemen risiko tersebut berpengaruh terhadap nilai perusahaan. Nampaknya kerangka COSO 2017 sudah diterapkan pada perbankan di Indonesia, namun hanya saja penamaannya berbeda yang terdapat pada laporan keuangan perusahaan. Profitabilitas pada penelitian ini berpengaruh negatif dan tidak signifikan. Hal ini karena pada tahun 2015-2017 rata-rata industri perbankan mengalami penurunan. Disisi lain ratarata nilai perusahaan pada perbankan di Indonesia memiliki nilai yang stagnan. Profitabilitas juga tidak mampu untuk memediasi pengungkapan manajemen risiko dengan nilai perusahaan. Hal tersebut karena besar kecilnya profitabilitas yang dihasilkan perbankan bukan menjadi penentu perusahaan dalam mengelola aktivitas manajemen risiko. Perusahaan mengalami penurunan profitabilitas disebabkan oleh faktor internal dan eksternal, hal tersebut tidak memengaruhi penilaian investor terhadap entitas perbankan tersebut. Penerapan 
serta pengungkapan manajemen risiko yang dilakukan manajemen semata-mata bukan karna besar kecilnya laba yang diperoleh, akan tetapi karena tanggung jawab entitas tersebut kepada pemegang saham dan kewajiban dari regulasi yang ada.

Penelitian ini terbatas pada sektor perbankan. Pengukuran manajemen risiko menggunakan COSO 2017. Penelitian selanjutnya bisa dikembangkan dengan sektor lain selain perbankan seperti industri non finansial. Kemudian alat ukur pengukuran manajemen risiko bisa digantikan dengan ISO 31000 yang berlaku di Indonesia. Penelitian selanjutnya bisa menggunakan indikator lain untuk profitabilitas seperti ROE dan NPM sehingga hasil yang berbeda pengaruhnya terhadap nilai perusahaan.

\section{DAFTAR PUSTAKA}

Agustiani, R. M. (2016). Pengaruh good corperate goverance, return on asset, return on equity, bopo dan capital adequacy ratio terhadap nilai perusahaan go publik di bursa efek Indonesia. Jurnal Ekonomi Bisnis, Vol. 21 No.2 pp. 131-135.

Agustina, L., \& Baroroh, N. (2016). The relationship between enterprise risk management and firm value mediated through the financial performance. Review of Integratif Business and Economic Research, Vol. 5 No. 1 pp. 128138.

Anton, S. G. (2018). The impact of enterprise risk management on firm value: empirical evidence from Romanian non-financial firms. Inzinerine EkonomikaEngineering Economics, Vol. 2 No. 29 pp. 151-157.

Attar, D., Islahuddin, \& Shabri, M. (2014). Pengaruh penerapan manajemen risiko terhadap kinerja keuangan perbankan yang terdaftar di bursa efek Indonesia. Jurnal Akuntansi : Pascasarjana Universitas Syiah Kuala, Vol. 3 No. 1 pp. 10-20.

Azim, M. H., \& Abdelmoniem, Z. (2015). Risk management and disclosure and their impact on firm value : the case of egypt. International Journal of Business, Accounting and Finance, Vol. 9 No. 1 pp. 114.

Bank Indonesia. Peraturan Bank Indonesia Nomor: 13/1/PBI/2011 tentang Penilaian Tingkat Kesehatan Bank Umum.

Bank Indonesia. Surat Edaran Bank Indonesia Nomor: 13/23/DPNP/tanggal 25 Oktober 2011 perihal Perubahan atas Surat Edaran No. 5/21/DPNP perihal Penerapan Manajemen Risiko bagi Bank Umum.

Brigham, \& Daves. (2010). Intermediate Financial Management. Tenth Edition. South Western: Cengage Learning.

Brigham, E., \& Ehrhardt. (2005). Financial Management Theory and Practice (Eleven Ed). Ohio: South Western Cengage Learning.

Brigham, E., \& Houston, J. (2014). Dasar-Dasar Manajemen Keuangan. Jakarta: Salemba Empat.

Cahyaningtyas, S. R., \& Sasanti, E. E. (2019). Penerapan manajemen risiko bank, tata kelola perusahaan dan kinerja perusahaan perbankan Indonesia. Jurnal Aplikasi Akuntansi, Vol. 3 No. 2 pp. 170-206.

Connelly, B., Certo, S., Ireland, R., \& Reutzel, C. (2011). Signaling theory: a review and assessment. Journal of management, Vol. 1 No. 37 pp. 39-67. 
Committe of Sponsoring Organization (COSO) of The Treadway Commision. 2017. Enterprise Management Framework Integrating with Strategy and Performance. Juni 2017

Devi, S., Budiasih, I. G., \& Badera, I. D. (2017). Pengaruh pengungkapan enterprise risk management dan pengungkapan intellectual capital terhadap nilai perusahaan. Jurnal Akuntansi dan Keuangan Indonesia, Vol. 14 No. 1 pp. 2045.

Dianawati, C. P., \& Fuadati, S. R. (2016). Pengaruh CSR dan GCG terhadap nilai perusahaan : profitabilitas sebagai variabel intervening. Jurnal Ilmu dan Riset Manajemen, Vol. 5 No. 1 pp. 120.

Donaldson, T., \& Preston, L. (1995). The stakeholder theory of the corporation: concepts, evidence, and implications. The Academy of Management Review, Vol. 1 No. 20 pp. 65-91.

Fama, E. F. (1978). The effect of a firm's investment and financing decision on the welfare of its security holders. American Economic Review, Vol. 98 pp. 271-282.

Faster, J., \& Simkins, B. (2007). Ten common misconceptions about enterprise risk. Journal of Applied Corporate Finance, Vol. 4 No. 19 pp. 75-81.

Freeman, R. (1994). The politics of stakeholder theory: some future directions. Business Ethics Quarterly, Vol. 4 No. 4 pp. 409421.

Freeman, R., Wicks, A., \& Parmar, B. (2004). Stakeholder theory and the corporate objective revisited. Organization Science, Vol. 15 No. 3 pp. 364-369.
Hoyt, \& Lienberg. (2011). The value of enterprise risk management. Journal of Risk and Insurance.

Jensen, M., \& Meckling, W. (1976). Theory of the firm: Managerial behavior. Journal of Finance Economic, Vol. 3 pp. 305-360.

Lin, Y., Wen, M., \& Yu, J. (2011). Enterprise risk management: strategic antecedents, risk integration and performance. North American Actuarial Journal, No. 16 pp. 0-48.

LMcShane, M., Nair , A., \& Rustambekov, E. (2011). Does enterprise risk management increase firm value? Journal of Accounting, Auditing and Finance.

Meulbroek, L. (2002). Integrated risk management for the firm: a senior manager's guide. Journal of Applied Corporate and Finance, No. 14 pp. $56-70$.

Moeller, R. (2011). COSO Enterprise Risk Management: $\quad$ Establishing Effective Governance, Risk, and Compliance Processes. New Jersey: John Wiley \& Sons, Inc.

Myers, S., \& Majluf, N. (1984). Corporate financing and investment decisions when firms have information that investors do not have. Journal of Financial Economics, Vol. 13 pp. 187-221.

Nocco, B., \& Stulz, R. (2006). Enterprise risk management: theory and practice. Journal of Applied Corporate Finance, Vol. 4 No. 18 pp. 8-20.

Nugraha, D. P. (2013). Efek penerapan enterprise risk management studi empiris pada reaksi pasar dan kinerja perusahaan. Tesis Universitas Gajah Mada.

Olayinka, E., Emoarehi, E., Jonah, A., \& Ame, J. (2017). Enterprice risk management and financial performance: evidence from 
emerging market. International Journal of Management, Accounting and Economics, Vol. 4 No. 9 pp. 937-952.

Otoritas Jasa Keuangan. Peraturan Otoritas Jasa Keuangan Nomor 13/PJOK.03/2015 tentang Transparansi dan Publikasi Laporan Bank.

Sartono, A. (2010). Manajemen Keuangan Teori dan Aplikasi. Edisi Keempat. Yogyakarta: BPFE.

Sayilir, Ö., \& Farhan, M. (2017). Enterprise risk management and its effect on firm value in Turkey. Journal of Management Research, Vol.9 No. 1 pp. 86-99.

Setyorini, C. T., \& Ishak, Z. (2012). Corporate social and environmental disclosure: a positive accounting theory view point. International Journal of Business and Social Science, Vol. 3 No. 9 pp. 152-164.

Solikhah, D. R., \& Hariyati. (2018). Pengaruh pengungkapan enterprise risk management terhadap nilai perusahaan dengan profitabilitas sebagai variabel mediasi. Jurnal Akuntansi Akunesa, Vol. 6 No. 3 pp. 1-20.

Sugiyanto, \& Rahayu, A. A. (2018). The implementation of risk management and its effect on good cooperative governance and success. Journal of Indonesia Economy and Business, Vol. 33 No. 3 pp. 3243-3256.
Sutedja. (2006). Pengungkapan (disclosure) laporan keuangan sebagai upaya mengatasi asimetri informasi. Jurnal Infestasi, Vol. 3 No. 2 pp. 113-125.

Taufik Fajar. Okefinance. Okezone.com. 1810 19. (Online). Avaible: https://economy. okezone.com/read/2019/10/18/32 0/2118645/kondisi-perbankan-5tahun-terakhir-masalah-di-kreditmacet

Thaib, I., \& Dewantoro, A. (2017). Pengaruh profitabilitas dan likuiditas terhadap nilai perusahaan dengan struktur modal sebagai variabel intervening. Jurnal Riset Perbankan Manajemen dan Akuntansi, Vol. 1 No. 1 pp. $25-$ 44.

Tui, S., Nurnajamuddin, M., Sufri, M., \& Nirwana, A. (2017). Determinant of profitability and firm value : evidence from Indonesia Banks. International Journal of Management \& Social Sciences, Vol. 01 No. 01 pp. 84-95.

Verrechia, R. E. (1983). Discretionary Disclosure. Journal of Accounting and Economics, Vol. 5 pp. 179-194.

Wendiyanto Saputro. Kumparan. Kumparan.com. 22112017. (Online). Avaible: https:// kumparan.com/kumparannews/lp s-ungkap-penyebabprofitabilitas-bank-terusmenurun/full 